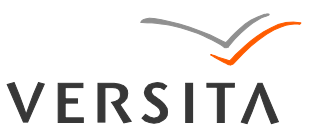

GEOCHRONOMETRIA 40(1) 2013: 42-50

DOI 10.2478/s13386-012-0022-4

Available online at

www.springerlink.com

\title{
THE RESULTS OF THERMOLUMINESCENCE DATING IN THE HALYCH IIC (UKRAINE) PROFILE AS THE EXPRESSION OF THE CONDITIONS OF MINERAL MATERIAL DEPOSITION
}

\author{
MARIA LANCZONT ${ }^{1}$, ANDRIJ B. BOGUCKI ${ }^{2}$, JAROSŁAW KUSIAK ${ }^{1}$ and OLEKSANDR SYTNYK ${ }^{3}$ \\ ${ }^{I}$ Department of Physical Geography and Palaeogeography, Maria Curie-Skłodowska University, \\ Al. Kraśnicka 2 cd, 20-718 Lublin, Poland \\ ${ }^{2}$ Department of Geomorphology and Palaeogeography, Ivan Franko National University, \\ Doroshenka 41, 79000 Lviv, Ukraine \\ ${ }^{3}$ Ivan Krypiakevich Institute of Ukrainian Studies, National Academy of Sciences of Ukraine, \\ Kozelnytskaya 4, 29008 Lviv, Ukraine
}

Received 29 June 2012 Accepted 14 November 2012

\begin{abstract}
Many studies conducted in the last few years in Poland indicate that the results of thermoluminescence dating of loess are reliable and correspond well to their geological ages. They can form the basis for determination of the chronology of changes of palaeoenvironmental conditions. In this paper we report dating results from the Halych IIC profile (Halych Prydnistrov'ja region, Ukraine). Thermoluminescence dating of this profile gives new information about the influence of local conditions on the results of TL analysis. As much as $75 \%$ of the obtained results are distinctly overestimated, even by several hundred per cent, that is untypical of regional loess profiles. However, in the Halych Prydnistrov'ja region it is the second loess site in which such incompatibility of the expected age and thermoluminescence age is found. This fact indicates how this region is unique among the loess areas of SE Poland and NW Ukraine in respect of the conditions of mineral material transport and deposition. Further investigations are necessary to identify the reasons for regular overestimating of the TL results obtained for loess deposits of the Halych Prydnistrov'ja region.
\end{abstract}

Keywords: TL dating, loess, Vistulian, Halych.

\section{INTRODUCTION}

Thermoluminescence (TL) dating of loess has been practiced successfully since at least 1981 (Wintle, 1981). Earlier applications to silt and sand grains from within loess have been critiqued by Wintle and Huntley (1982). Many later applications and difficulties have been reviewed by Berger $(1988,1995)$ and Aitken (1998). Contrary to initial expectations, the light-sensitive component

Corresponding author: J. Kusiak

e-mail: jaroslaw.kusiak@umcs.lublin.pl in the TL from loess (and sand dunes) is not always reduced to zero before burial. This has been deduced by tests for the presence of residual (inherited) lightsensitive TL in modern-analogue deposits of loess or of surface sands, reviewed by Berger (1988). There is good evidence that the amount of light-sensitive TL in primary (aeolian, not re-worked) loess depends on the transport distance of the grains, that is, on the duration of daylight exposure during transport. Lu et al. (1987) showed that about 12 hours of daylight exposure was needed to reduce the light-sensitive TL to zero (to 'reset' the TL clock). 
Berger (1987) showed that a large fraction of lightsensitive TL remained in the silt from surface loess transported only $2-3 \mathrm{~km}$, thus exposed to daylight for less than an hour (a few minutes?). There is also some evidence that clumping or clustering of silt grains (by carbonate cementation) during aeolian transport can shield some silt grains from daylight and thus prevent effective zeroing of the luminescence clock (e.g., Lian and Huntley, 1999). Finally, coating or staining of the surface of grains by iron oxides (e.g., goethite and limonite) can reduce or prevent the penetration of daylight at certain wavelengths (Berger, 1988), thus reducing the effectiveness of zeroing of light-sensitive TL during grain transport, whether by wind or water.

Given these observations, it is not surprising that accurate TL dating of non-aeolian sediments such as till has proven to be unreliable at best, impossible at worst. More recently, silts and sands from some lacustrine, marine and fluvial deposits (e.g., Berger and Anderson, 2000; Bluszcz, 2000; Ber, 2002; Oczkowski, 2002) appear to give accurate TL age estimates. Indeed, the main reason TL dating is no longer commonly practiced is that the much more sensitive optically-stimulated-luminescence (OSL, or PSL, Aitken, 1998) methods (e.g., Lian and Roberts, 2006) can more easily provide accurate luminescence ages for non-aeolian deposits than TL can. Nonetheless, TL can be accurate for loess and for this reason we have applied it to the deposits at Halych (Fig. 1), with unexpected results.

In the light of the studies presented above, the TL dating results obtained for loesses from the Kolodiiv site (Halych Prydnistrov'ja region, East Carpathian Foreland,

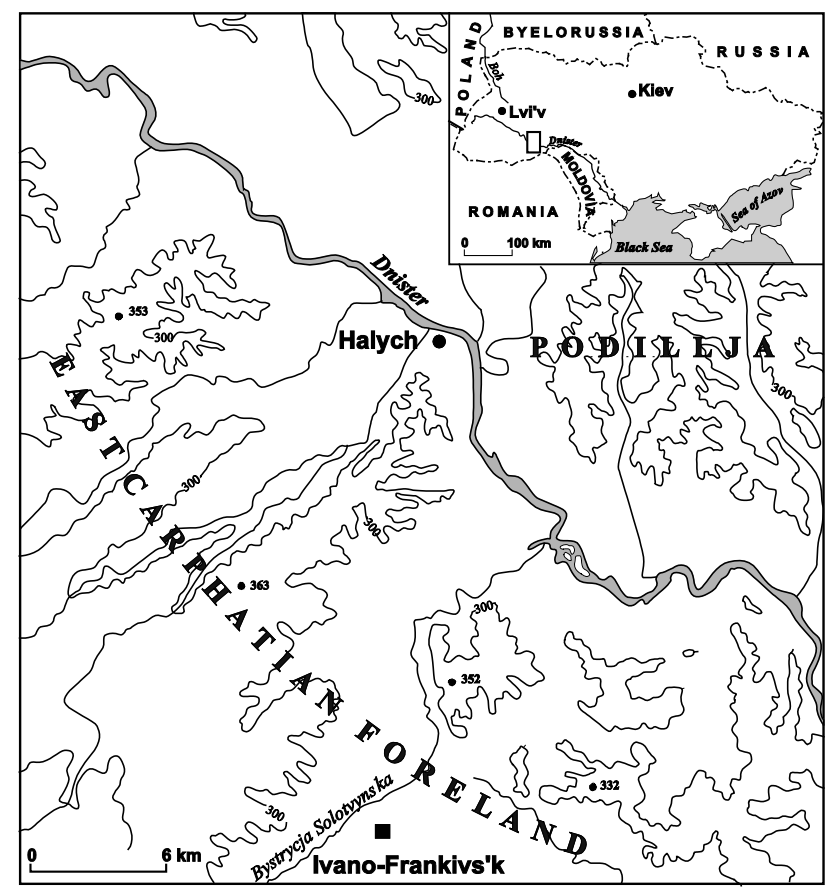

Fig. 1. Location of the Halych (Halicz) site, after Bogucki et al. (2009).
Ukraine) were very surprising (Kusiak, 2007; Łanczont and Boguckyj, 2007). The detailed lithologic and stratigraphic investigations indicated that the very thick loess cover should be related to the Early Vistulian and Plenivistulian periods. However, only about $50 \%$ from among 17 obtained TL ages of loess samples agreed with stratigraphic interpretation (Łanczont and Boguckyj, 2007). The rest of the results were much overestimated, and the values of TL age did not increase with the depth.

These results can indicate that mineral material composing different deposit layers originated from different alimentation sources, so the route and time of transport could have been different. The lack of TL age sequence in vertical profiles undermines the possibility of using the results of TL dating to determine the chronology of changes of palaeoenvironmental conditions.

However, it should be considered if the overestimated TL ages of loesses are obtained commonly or perhaps only locally. Their local nature could have been indicated by the results of many research works conducted in Poland in the last years, among others those published by Fedorowicz (2006) and Kusiak (2006). Fedorowicz (2006) presented over 100 results of TL dating of loesses from the Polish and Ukrainian Carpathians and Carpathian Foreland and from the Sudetes Foreland, and Kusiak (2006) - over 100 results obtained for loesses from the South Polish Upland belt. The conclusions are similar. The obtained TL ages of loesses from the regions mentioned are reliable and very well correspond to their geological ages. They can form the basis for determination of the chronology of changes of palaeoenvironmental conditions.

Based on the results of the papers mentioned above, it can be supposed that the results obtained for the Kolodiiv site were overestimated due to local conditions of the Halych Prydnistrov'ja region. Such an interpretation is supported by the results of TL dating obtained for the Halych IIC profile.

\section{HALYCH IIC PROFILE}

Halych town is situated in the Halych-Bukachev Basin, at the mouth of the Lukva River to the Dniester River, within the Halych Prydnistrov'ja region (Fig. 1) (Łanczont and Boguckyj, 2002).

The loess site exposed near a discarded working of brick-yard, on the outskirts of Halych town, is one of the most important, key exposures of the Upper and Middle Pleistocene in the Prydnistrov'ja area. Excellently developed series of loesses with four paleosols of interglacial rank (from S1 to S4) is several dozen metres thick. Moreover, in 1997 Bandrowski discovered in this place an important Palaeolithic site with the traces of many settlement phases. First geological investigations at the Halych site were conducted in the years 1998-2001 as part of the research project 6P04E 03115 . The following profiles were examined then: I, IA, IB - loesses of the 
Vistulian Glacial (L1) with cultural layers, II, IIA - loesses of the Vistulian, Wartanian and Odranian Glacials (L1, L2, L3), and with cultural layers too but not in situ, III, IV - deposits older than the Odranian Glacial (L4, L5). This thick subaerial mantle covers gravelly-sandy and silty series of fluvial origin (V profile) belonging to the Dniester River terrace. It is the Pleistocene fifth terrace occurring at $62-72(80) \mathrm{m}$ above the valley bottom (Lanczont and Boguckyj, 2002). Based on the exposures examined so far, it was found that the Halych terrace is characterized by complex internal structure in the layers younger than the Lublinian Interglacial. The youngest loesses (L1) from the Vistulian Glacial are thin but distinctly diverse in terms of stratigraphy. Under these loesses the Eemian soil is preserved in parts, though denudation traces are visible in its top in places (the set of exposures of the IIA profile). This is rather typical of the high terraces of the Dniester River where loesses from the Last Glacial are thin or absent.

In comparison with this situation, the Halych IIC profile (a detailed lithological description of Halych IIC profile is presented in Table 1) is rather peculiar. It is exposed in a deep, V-shaped cutting situated in the west- ern part of the discarded working of brick-yard. In this profile the Vistulian loesses are over $12 \mathrm{~m}$ thick and stratigraphically differentiated, and the underlying Eemian soil is completely preserved together with the A horizon of interglacial soil, which is a rare phenomenon. It should be stressed that traces of denudation (especially solifluction) are almost absent in this profile though they are common in other exposures in the brick-yard area. The Halych IIC profile is situated at a distance of $70-80 \mathrm{~m}$ in a straight line both from the IIA and I profiles where loess thickness is far smaller (about $6 \mathrm{~m}$ and $3 \mathrm{~m}$, respectively). This spatial diversity of the Vistulian loess thickness indicates that post-Eemian deposition surface was uneven; recent surface of the fifth terrace is rather smooth.

Investigations in the Halych IIC site started in 2007. The exposure was specially prepared by the team of archaeologists under the direction of O. Sytnyk. They searched after cultural layers with artefacts in situ. The site turned out to be devoid of archaeological content but the litho-stratigraphic diversity of the profile encouraged us to sample it for thermoluminescence, palaeomagnetic, isotope and chemical analyses.

Table 1. Lithological description of Halych IIC profile.

\begin{tabular}{|c|c|}
\hline Depth (m) & Lithological description \\
\hline \multicolumn{2}{|c|}{ Recent soil. Variable thickness $(0.7-1.0 \mathrm{~m})$ due to reduction of soil profile from the top during works in the brick-yard area } \\
\hline $0-0.3$ & $\begin{array}{l}\text { Humus horizon, silty-sandy, dark-grey (7.5 YR6/1), anthropogenically transformed (admixture of brick, glass, coal and the like); non- } \\
\text { calcareous. }\end{array}$ \\
\hline $0.3-0.95$ & $\begin{array}{l}\text { Illuvial horizon of forest soil, silty-sandy, of prismatic structure, reddish-brown (10YR 6/8), with stains of bleaching in the upper part, } \\
\text { strongly fissured; non-calcareous. }\end{array}$ \\
\hline $0.95-1.20$ & $\begin{array}{l}\text { Buff loess (10YR8/4), microporous, homogeneous, with numerous carbonate pseudomycelia and larger concretions (dolls); calcare- } \\
\text { ous. } \\
\text { TL16 }-1.10 \mathrm{~m}\end{array}$ \\
\hline \multicolumn{2}{|c|}{ Paleosol, brown earth } \\
\hline $1.20-1.80$ & $\begin{array}{l}\text { A - humus horizon, silty-sandy, red-brown (10YR5/4), but in middle and lower parts gleyed, with bleaching traces (?), shade is } \\
\text { lighter, rather compact, with numerous black iron-manganese concretions ( } 2-3 \mathrm{~mm} \text { in diameter); calcareous weakly (secondary } \\
\text { carbonates occur). The horizon is strongly biogenically transformed, with numerous traces of the existence of small burrowing } \\
\text { animals (casts of tunnels). Very distinct upper boundary. } \\
\text { Several Palaeolithic artefacts, probably redeposited, were found in the upper part of the horizon. } \\
\text { TL15-1.50 m }\end{array}$ \\
\hline $1.80-2.60$ & $\begin{array}{l}\text { Bbr1 - silty-sandy, brown-reddish (10YR6/8), stratified (several cm thick layers), gleyed, with numerous black and rust-coloured iron- } \\
\text { manganese concretions, with crotovinas filled with loess material; non-calcareous, calcareous only near carbonate concretions. }\end{array}$ \\
\hline $2.60-3.10$ & $\begin{array}{l}\mathrm{B}_{\mathrm{b}} 2 \text { - silty-sandy, buff-rust-coloured (10YR7/6), indistinctly stratified, but strata planes are accentuated by gleying sins and coatings } \\
\text { of iron and manganese oxides. Rust-coloured and black iron-manganese concretions are very numerous; calcareous. Small fissures } \\
\text { reaching this sub-horizon begin above. Very distinct lower boundary. }\end{array}$ \\
\hline $3.10-5.80$ & $\begin{array}{l}\text { Typical loess, silty, buff (10YR8/3), homogeneous, with numerous carbonate pseudomycelia, iron-manganese concretions; calcare- } \\
\text { ous. Lower boundary distinctly visible as colour change. Fissured loess, with traces of translocation along fissure planes, fissures } \\
\text { accentuated by coatings of manganese oxides, streaks enriched with iron and manganese compounds accentuate grain size varia- } \\
\text { bility and disturbed internal structure of the layer, crotovines are filled with red-rust-coloured clayey material coming probably from } \\
\text { the overlying soil. } \\
\text { TL14 }-3.10 \mathrm{~m} \\
\text { TL13 }-4.30 \mathrm{~m} \\
\text { TL12 }-5.70 \mathrm{~m}\end{array}$ \\
\hline $5.80-6.20$ & $\begin{array}{l}\text { Horizon of initial pedogenesis (Rivne?), gleyed, silty-sandy, rather homogeneous and compact, grey and bluish-grey (10YR7/3), } \\
\text { with distinct plication deformations in places, with numerous iron-manganese concretions; calcareous very intense. Distinct lower } \\
\text { boundary, with initial (ok. } 0.5 \mathrm{~cm} \text { ) hardpan streak. }\end{array}$ \\
\hline
\end{tabular}


Table 1. Continuation.

Depth $(\mathrm{m}) \quad$ Lithological description

6.20-7.30 Silty-sandy loess of variable thickness (1.1-1.2 m), gleyed, dark-buff with bluish tint (10YR8/3), rather homogeneous, with stains and wavy streaks - rust-coloured iron and black manganese, Liesegang rings $(2-2.5 \mathrm{~cm}$ in diameter), iron-manganese concretions and carbonate pseudomycelia are numerous; calcareous very intense.

TL11 $-6.30 \mathrm{~m}$

TL10 $-7.20 \mathrm{~m}$

7.30-7.60 Gley horizon with uneven upper boundary, silty-sandy, bluish-grey with rust tint (7.5YR7/2), strongly gleyed, with numerous soft rustcoloured iron-manganese concretions and Liesegang rings, with plication deformations. Distinct lower boundary.

TL9 $-7.50 \mathrm{~m}$

7.60-7.90 Less of variable thickness, maximum up to $0.3 \mathrm{~m}$, silty-sandy, buff (7.5YR6/3), rather homogeneous, with carbonate pseudomycelia and small concretions $1 \mathrm{~cm}$ in diameter, with iron-manganese concretions ( $3 \mathrm{~mm}$ in diameter); calcareous. Uneven lower boundary. TL8 $-7.80 \mathrm{~m}$

7.90-8.35 Gley horizon, silty-sandy, bluish-grey (7.5YR7/2), enriched with iron compounds, with rust-coloured streaks, with numerous ironmanganese concretions and carbonate pseudomycelia; calcareous. Layer with plication deformations, broken by small wedge-like structures, probably of cryogenic origin, running from the intersoil loess. Distinct, sinuous lower boundary.

TL7 - $8.10 \mathrm{~m}$

8.35-9.55 Silty-sandy loess, buff (7.5YR7/3), homogeneous, microporous, spotty (gley stains $1 \mathrm{~cm}$ in diameter and lenses of material impregnated with manganese compounds) especially in the upper part of the layer; calcareous very intense, numerous secondary carbonates (pseudomycelia). Very uneven lower boundary.

TL6 $-8.50 \mathrm{~m}$

TL5 $-9.50 \mathrm{~m}$

9.55-9.95 Initial gley soil III (from bottom), silty-sandy, bluish-grey (7.5YR7/1), light-brown (7.5YR6/6) in the upper part (5-10 cm), with numerous iron stains and black iron-manganese concretions, especially in the upper part; calcareous. Thickness of the layer is horizontally variable due to very uneven upper and lower boundaries.

9.95-10.55 Coarse silty loess, homogeneous, buff (7.5YR7/3), with carbonate pseudomycelia, manganese and iron stains and single ironmanganese concretions; calcareous.

TL4 - $10.20 \mathrm{~m}$

10.55-11.05 Initial gley soil II (from bottom), silty-sandy, bluish-grey (7.5 YR 7/1), with numerous rust-coloured and black iron-manganese concretions (up to $5 \mathrm{~mm}$ in diameter); calcareous. Fissures, spaced $10 \mathrm{~cm}$ apart, filled with gley material, run downwards from the upper boundary of the layer. Undulated black streak formed by concentration of iron-manganese concretions occurs in the lower part of the layer. Distinct lower boundary.

11.05-11.45 Silty-sandy loess, rather compact, homogeneous, with gley stains and rust-coloured, more rarely black, iron-manganese concretions (up to $3 \mathrm{~mm}$ in diameter); calcareous very weakly.

TL3 - $11.20 \mathrm{~m}$

$\overline{11.45-12.00}$ Initial gley soil I, silty, buff, bluish-grey in places (7.5YR7/3 and 7/1). Distinctive rust-coloured and gley grey stains, very numerous small iron-manganese concretions, rust-coloured, more rarely black (up to $3 \mathrm{~mm}$ in diameter) and stains of manganese compounds (about $1 \mathrm{~cm}$ in diameter). Fissures filled with loess material run downwards from the upper boundary of the layer, there are also fissures running from the overlying layers; calcareous, but in the lower part of the layer $(0.2 \mathrm{~m})$; non-calcareous.

12.00-12.25 Silty-sandy loess, dark-buff (7.5YR7/4), gleyed in places (gley stains up to do $2 \mathrm{~cm}$ in diameter), with iron-manganese stains and single small, $(2 \mathrm{~mm})$ carbonate concretions; calcareous very weakly. Distinct boundary. TL2 - $12.10 \mathrm{~m}$

12.25-12.40 The A horizon of interglacial soil, coarse silt, coffee-coloured-grey, rather homogeneous, gleyed, with numerous black and rustcoloured iron-manganese concretions up to $3 \mathrm{~mm}$ in diameter; non-calcareous. Gradual transition. TL1 - $12.30 \mathrm{~m}$

12.40-12.65 The Eet horizon of interglacial soil, coarse silt, loose, homogeneous, light-brown (7.5YR8/2) with lighter places and stains of gleying, and with numerous small (up to $3 \mathrm{~mm}$ in diameter) black iron-manganese stains; non-calcareous. Lower boundary distinctly visible as colour and lithology change.

12.65-13.40 The Btg horizon of interglacial soil, with crumb structure, silty-sandy, strongly gleyed, especially in the upper part, compact, broken by fissures about $1 \mathrm{~cm}$ wide, filled with gley material, very dense (every 5-10 cm), impregnated with iron compounds, reddish-rustcoloured (7.5YR7/6); non-calcareous. Black, weakly compact iron-manganese concretions are very numerous.

\section{DATING METHOD}

The TL age is a quotient of equivalent dose $\left(D_{e}\right)$ and dose rate $\left(D_{r}\right)$. Equivalent dose is the laboratory dose of $\beta$ or $\gamma$ radiation, which produces the same thermoluminescence as that produced by the dose absorbed by the examined sample under natural conditions. Dose rate is the effective dose of ionizing radiation absorbed by the examined sample in a unit of time.

The dose rate was obtained as a sum of components $\mathrm{d}_{\alpha}, \mathrm{d}_{\beta}, \mathrm{d}_{\gamma}$ coming from $\alpha, \beta$ and $\gamma$ radiation emitted by isotopes occurring in deposit and the correction $d_{c}$ for cosmic radiation. Dose rates were calculated from the measured concentrations of natural radionuclides ${ }^{40} \mathrm{~K}$, 
${ }^{226} \mathrm{Ra},{ }^{228} \mathrm{Th}$ (Table 2). The measurements were carried out in the laboratory using a three-channel, stationary gamma spectrometer type MAZAR-95 produced by Polon-Izot Warszawa (Poland), assuming age equilibrium state in the radioactive series (Poręba and Fedorowicz, 2005). The measurements of radioisotopes were carried out with the application of Marinelli-type containers for the deposit portions of about $0.6 \mathrm{dm}^{3}$ in capacity. The measurement time was $80000 \mathrm{~s}$. The concentrations of radioisotopes obtained in $\mathrm{Bq} / \mathrm{kg}$ were converted into absorbed dose rates for $\alpha, \beta$ and $\gamma$ radiation in $\mathrm{Gy} / \mathrm{ka}$, based on the data published by Adamiec and Aitken (1998) and Olley et al. (1996). The calculation of the correction for cosmic radiation was based on the data published by Prescott and Hutton (1994). The correction $\mathrm{k}=0.1$ (for small effectiveness of generating thermoluminescence when subjected to $\alpha$ radiation) was taken (cf. Benea et al., 2007). The $\mathrm{D}_{\mathrm{r}}$ was calculated with the correction for sample moisture of about $18 \%$.

The equivalent dose was determined by the totalbleach method described by Singhvi et al. (1982). All sample preparation was carried out under red light conditions with use Kaiser spectral 590 lamp. From the mass of sample the $45-63 \mu \mathrm{m}$ polymineral fraction was separated by wet sieving, and then treated with $10 \% \mathrm{HCl}$ to remove carbonates and with $30 \% \mathrm{H}_{2} \mathrm{O}_{2}$ to remove organic material (Balescu et al., 1991). The mineral material was divided into six portions. One portion was used to determine the natural thermoluminescence. The second portion was exposed to light from an ultraviolet lamp of OSRAM ULTRA-VITALUX type for about 12 hours, in order to determine the residual level of thermoluminescence. The remaining four portions were irradiated with the ionising radiation doses from a ${ }^{60} \mathrm{Co} \gamma$ source $(300 \mathrm{~Gy}, 500 \mathrm{~Gy}$, $1000 \mathrm{~Gy}$ and $2000 \mathrm{~Gy}$ ). The samples have been preheated for $3 \mathrm{~h}$ at $120^{\circ} \mathrm{C}$ prior to glowing (Berger et al., 1992).
The glow curves were recorded using a RA'94 TL reader/analyser (with the EMI 9789 QA photomultiplier) produced by Mikrolab Kraków (Poland) linked with an IBM computer. Aliquots were glowed out in argon atmosphere at a heating rate of $10^{\circ} \mathrm{C} / \mathrm{s}$ up $400^{\circ} \mathrm{C}$. An optical filter HA-3 was used to cut infra-red radiation of the platinum heater. The TL light sum was read under narrow region $10^{\circ} \mathrm{C}$ of the TL glow curve, which includes its maximum (Kusiak et al., 2012). In order to determine the $D_{e}$ value, about thirty sub-samples of $4 \mathrm{mg}$ in weight were taken from each portion. An exponential saturation function was fitted to the obtained points with the use of the FIT-SIM programme (Grün, 1994), which was based on the simplex fitting procedures and analytical error calculation described by Brumby (1992). Irradiation of samples (in the Institute of Nuclear Chemistry and Technology, Warszawa, Poland) and thermoluminescence measurements (in Lublin laboratory) were carried out at least a month apart. For this reason, it was not possible to carry out a full test for anomalous fading as described by Huntley and Lamothe (2001). Confidence interval of the obtained values of TL age is $68 \%$.

\section{STRATIGRAPHY OF THE HALYCH IIC LO- ESS-SOIL SEQUENCE}

The profile is $13.40 \mathrm{~m}$ thick. It is topped with modern soil (S0), and interglacial Eemian soil (S1) occurs in its bottom. Based on lithological and palaeopedological criteria, several loess beds separated by paleosols of different rank (interstadial, interphase) were distinguished in the profile and correlated with oxygen isotope stages. The Vistulian loesses (L1) sequence is complete $(12.25 \mathrm{~m})$ from the Early Vistulian to the Late Glacial layers.

Deposits correlated with MIS5 occur at a depth of 9.55-13.4 m. They contain the Eemian paleosol with main

Table 2. The concentrations of radioisotopes: $K, U$, Th, values of dose rate $\left(D_{r}\right)$, equivalent dose $\left(D_{e}\right)$ and $T L$ age of deposits from Halicz IIC profile.

\begin{tabular}{|c|c|c|c|c|c|c|c|}
\hline $\begin{array}{l}\text { Depth } \\
(\mathrm{m})\end{array}$ & $\begin{array}{c}\text { Sample } \\
\text { No. } \\
\text { Lub- }\end{array}$ & $\begin{array}{c}\mathrm{K} \\
(\mathrm{Bq} / \mathrm{kg})\end{array}$ & $\begin{array}{c}\mathrm{U} \\
(\mathrm{Bq} / \mathrm{kg})\end{array}$ & $\begin{array}{c}\text { Th } \\
\text { (Bq/kg) }\end{array}$ & $\begin{array}{c}\text { Dose rate } \\
D_{r} \\
\text { (Gy/ka) }\end{array}$ & $\begin{array}{c}\text { Equivalent dose } \\
\text { ED (Gy) }\end{array}$ & $\begin{array}{c}\text { TL age } \\
\text { (ka) }\end{array}$ \\
\hline 1.10 & 4530 & $518 \pm 23$ & $31.4 \pm 2.8$ & $40.7 \pm 2.1$ & $3.42 \pm 0.17$ & $45 \pm 5$ & $13.4 \pm 1.4$ \\
\hline 1.50 & 4529 & $494 \pm 22$ & $32.0 \pm 2.8$ & $37.4 \pm 2.0$ & $3.26 \pm 0.16$ & $211 \pm 36$ & $65 \pm 11$ \\
\hline 3.20 & 4528 & $482 \pm 2.3$ & $29.7 \pm 2.7$ & $44.4 \pm 2.2$ & $3.27 \pm 0.16$ & $351 \pm 78$ & $107 \pm 23$ \\
\hline 4.40 & 4527 & $529 \pm 24$ & $23.9 \pm 2.2$ & $38.4 \pm 2.0$ & $3.15 \pm 0.16$ & $282 \pm 55$ & $90 \pm 17$ \\
\hline 5.70 & 4526 & $524 \pm 25$ & $33.2 \pm 2.7$ & $41.2 \pm 2.1$ & $3.40 \pm 0.17$ & $239 \pm 53$ & $70 \pm 22$ \\
\hline 6.20 & 4525 & $582 \pm 26$ & $27.3 \pm 2.7$ & $46.1 \pm 2.2$ & $3.43 \pm 0.17$ & $339 \pm 56$ & $99 \pm 16$ \\
\hline 7.20 & 4524 & $580 \pm 27$ & $32.1 \pm 2.5$ & $42.3 \pm 2.2$ & $3.42 \pm 0.17$ & $280 \pm 54$ & $82 \pm 15$ \\
\hline 7.55 & 4523 & $525 \pm 2.4$ & $32.1 \pm 2.8$ & $43.2 \pm 2.2$ & $3.36 \pm 0.16$ & $225 \pm 52$ & $67 \pm 15$ \\
\hline 7.90 & 4522 & $498 \pm 22$ & $33.2 \pm 3.0$ & $38.0 \pm 2.0$ & $3.17 \pm 0.17$ & $499 \pm 82$ & $157 \pm 26$ \\
\hline 8.25 & 4521 & $616 \pm 25$ & $40.1 \pm 2.2$ & $48.6 \pm 2.1$ & $3.37 \pm 0.16$ & $352 \pm 62$ & $104 \pm 21$ \\
\hline 8.55 & 4520 & $478 \pm 22$ & $32.6 \pm 2.9$ & $41.3 \pm 2.2$ & $3.15 \pm 0.16$ & $329 \pm 51$ & $104 \pm 16$ \\
\hline 9.55 & 4519 & $502 \pm 18$ & $42.5 \pm 2.4$ & $48.7 \pm 1.9$ & $3.25 \pm 0.17$ & $261 \pm 36$ & $80 \pm 11$ \\
\hline 10.35 & 4518 & $512 \pm 19$ & $44.4 \pm 2.2$ & $46.8 \pm 1.9$ & $3.36 \pm 0.17$ & $270 \pm 85$ & $80 \pm 18$ \\
\hline 11.35 & 4517 & $489 \pm 2.3$ & $31.2 \pm 2.7$ & $43.2 \pm 2.2$ & $3.22 \pm 0.16$ & $486 \pm 95$ & $151 \pm 30$ \\
\hline 12.25 & 4516 & $533 \pm 24$ & $24.8 \pm 2.3$ & $44.9 \pm 2.2$ & $3.15 \pm 0.16$ & $474 \pm 96$ & $150 \pm 30$ \\
\hline 12.45 & 4515 & $516 \pm 23$ & $29.9 \pm 2.5$ & $42.2 \pm 2.4$ & $3.22 \pm 0.16$ & $355 \pm 70$ & $110 \pm 21$ \\
\hline
\end{tabular}


genetic horizons of lessive soil $(\mathrm{A}+\mathrm{Eet}+\mathrm{Bt})$ and the sequence of three initial gley soils separated by thin loess layers; these soils are related to interstadials and stadials of the Early Glacial. This whole multiple interglacialearly glacial pedocomplex represents the Horochiv s.l. stratigraphic unit (equivalent of the Pryluki pedocomplex in the central part of Ukraine), and in the NW part of Ukraine the interstadial horizons have their own name Kolodiiv set of palaeosols. Loess of the Lower Pleniglacial (MIS4) occurring at a depth of 8.35-9.55 m is siltysandy, buff coloured. Interpleniglacial is represented by two gley horizons separated by loess $(8.35-7.40 \mathrm{~m})$, and such situation is rather typical of loesses in the Prydnistrov'ja region (Boguckyj and Lanczont, 2002). The loess-soil sequence of the Middle Pleniglacial is correlated with the Dubno stratigraphic unit (equivalent of the Vytachiv unit in the central part of Ukraine). In some loess sites of the East Carpathian Foreland, Volyn and Podillya regions this sequence is very complex, e.g. in the Kolodiiv site where two interstadial pedocomplexes are separated by loess layer. The name Dubno 2 (set of palaeosols) was proposed for the older of them and Dubno 1 - for the younger one. However, only fragments of the Interplenivistulian loess-soil sequence are preserved in many profiles. It was caused by unstable climate of this period, with a series of warm and cool oscillations, which favoured activation of erosion and denudation processes resulting in the occurrence of hiatuses in the deposits. They were also intensively destroyed in the beginning of the Upper Pleniglacial when these processes were especially active (Lanczont and Bogucki, 2007). The profile of the Upper Pleniglacial loess (MIS2) is typical of the Podilljan Prydnistrov'ja region; in the lower part it is silty-sandy gleyed deposit of various thickness (1.1$1.2 \mathrm{~m}$ ), and in the upper part - typical loess, silty, very homogeneous and rather thick $(2.70 \mathrm{~m})$. These two series are separated by the Rivne horizon of heterogeneous structure (equivalent of the Dofinivka unit in the central part of Ukraine), the stratigraphic position of which is confirmed also by cultural layers at the Halych I neighbouring site (several pits). Brown earth soil, found in the upper part of the profile, is related to interphase warmings towards the end of glacial (Bölling and Alleröd) on account of its position in the profile and state of pedogenesis development. The Late Glacial loess separates this soil from the modern one. This situation is unique in the Podilljan loesses. However, the Late Glacial loess-soil sequence is found e.g. in loesses on the Black Sea coast (Gozhyk et al. 1995, 2001).

\section{THERMOLUMINESCENCE DATING RESULTS}

Based on the litho-stratigraphic study, the profile seemed to be perfect for making detailed thermoluminescence dating. However, the results of thermoluminescence analysis fell completely short of our expectations. Only four out of sixteen samples gave results corresponding to the expected ages. These samples were taken from the Late Glacial loess, Lower Plenivistulian loess, Early Vistulian loess and the A horizon of the Eemian soil. The remaining obtained results were distinctly overestimated, even by several hundred per cent. The results of thermoluminescence analysis are presented in Table 2 and Fig. 2.

\section{Loess of MIS 2}

The result obtained for the Late Glacial loess is $13.4 \pm 1.4 \mathrm{ka}$ (Lub-4530). It rather well corresponds to the expected age of the dated layer though it seems to be slightly overestimated. The underlying brown earth soil was TL dated at $65 \pm 11 \mathrm{ka}$ so its age is overestimated by several hundred per cent. Five dating results were obtained for the Upper Pleniglacial thick loess bed occur-

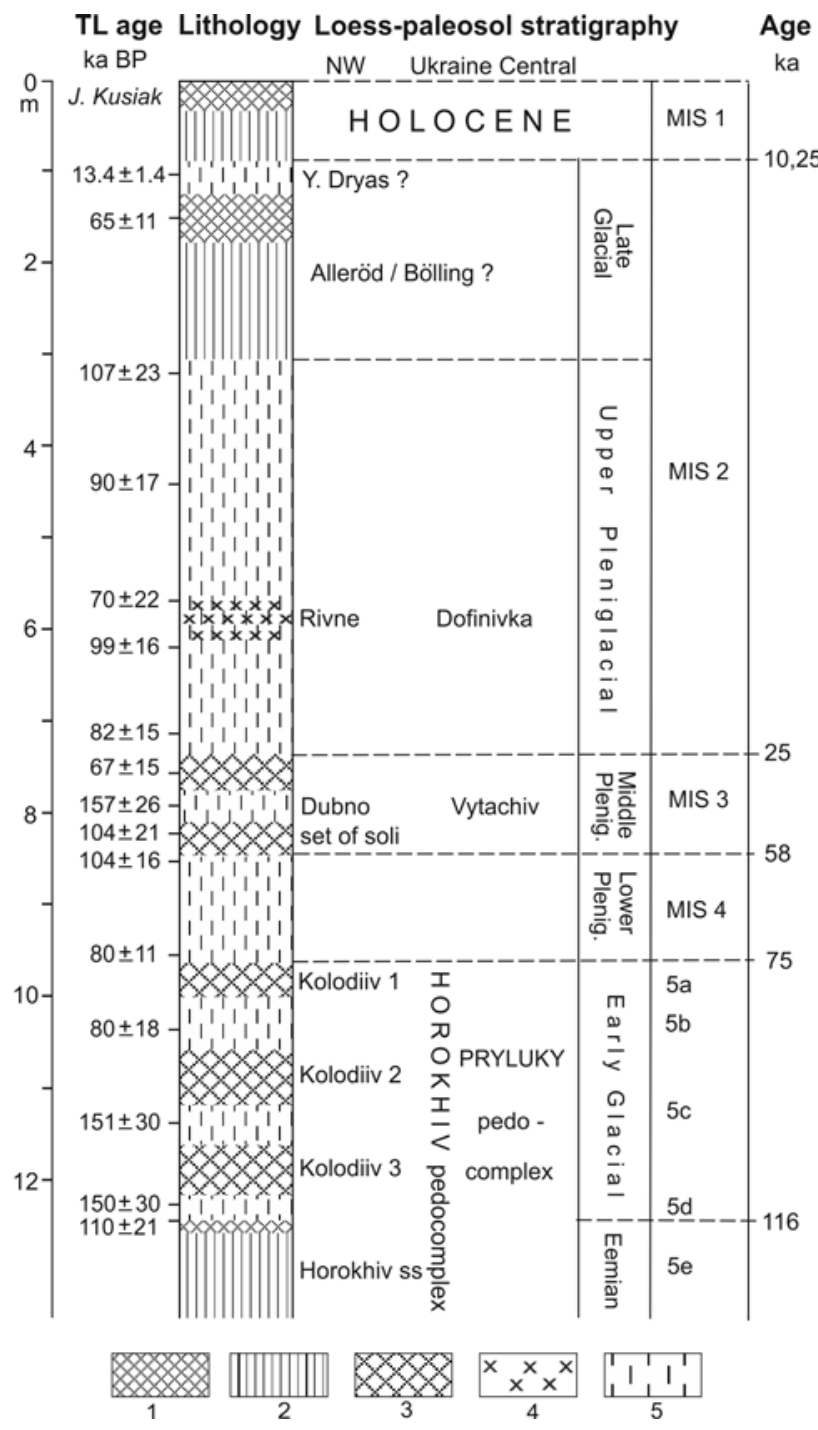

Fig. 2. Lithology, thermoluminescence age and stratigraphic setting of the loess-paleosol sequence in the Halych IIC (Halicz) profile. 1 - humus horizon, 2 - illuvial horizon of interglacial soil, 3 - interstadial soil, 4 - gley signs, 5 - loess. 
ring under this soil. This loess is divided into two parts by the Rivne horizon. Three loess samples taken over the Rivne horizon were TL dated at $107 \pm 23 \mathrm{ka}, 90 \pm 22 \mathrm{ka}$ and $70 \pm 22$ ka BP (Lub-4528-4526), and two samples taken below it - at $99 \pm 16 \mathrm{ka}$ and $82 \pm 15 \mathrm{ka} \mathrm{BP}$ (Lub-4525 and Lub-4524). Therefore, these TL ages are also incompatible with the real time of deposition. The Rivne horizon was not dated because of its complex structure.

\section{Loess of MIS 3}

The series composed of two gley horizons separated by loess layer yielded the following age estimates: upper

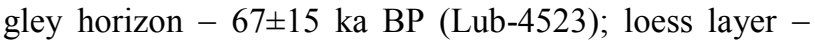
$157 \pm 26$ ka BP (Lub-4522); lower gley horizon $104 \pm 21$ ka BP (Lub-4521). It cannot be excluded that these two soils represent the older part of this stage and in fact are the Dubno 2 set of paleosols.

\section{Loess MIS 4}

This bed was TL dated at $104 \pm 16 \mathrm{ka}$ (Lub-4520) and $80 \pm 11 \mathrm{ka}$ (Lub-4519). If the time limits of the Lower Pleniglacial are accepted after Mojski (1999) at 75-58 ka BP, both obtained dates are overestimated but the latter only slightly.

\section{MIS 5a-d}

Three Early Glacial soils are separated and underlain by loess deposits. The loess layers were TL dated, and the following results were obtained, from top to bottom: $80 \pm 18$ ka BP (Lub-4518) - this result belongs to few dates corresponding to the expected age though it is slightly underestimated, two consecutive dates are much overestimated: $151 \pm 30 \mathrm{ka}$ BP (Lub-4517), $150 \pm 30 \mathrm{ka}$ BP (Lub-4516).

\section{MIS 5e}

The last TL date, $110 \pm 21$ ka BP (Lub-4515) was obtained for the horizon A of the Horohiv paleosol. It rather well corresponds to the deposition age of the dated deposit.

\section{DISCUSSION}

The TL ages obtained for the Halych IIC profile represent one of few unsuccessful attempts at dating of loess profiles in eastern Europe conducted in laboratory Department of Geoecology and Palaeogeography, Maria Curie-Skłodowska University in Lublin. The other sites where thermoluminescence method applied to the Vistulian loess profiles gave considerably overestimated results for most of the samples or for the whole profile, are the following sites: Kolodiiv (Halych Prydnistrov'ja region, Ukraine) (Kusiak, 2007) and Kończyce (Głubczyce Plateau, Poland) (Kusiak, unpublished data). The small number of such profiles suggests a local nature of deposition processes occurring near the mentioned sites.
As pointed out in the introduction, the time and conditions of exposure of mineral grains to sunlight in the past is of essential importance for the results of TL dating. The TL dates corresponding to the geological ages indicate that mineral grains were exposed to sunlight on ground surface for a long time. Sedimentation process was probably continuous and slow (Lu et al., 1987). The anomalous TL dates are connected with the occurrence of partially bleached material, probably of local origin, transported over a very short distance and probably by mass movements (Berger, 1987, 1988; Lian and Huntley, 1999).

A question arises about the source of deposited material. One of possible explanations can be related to the palaeorelief and its stability. Observations made in the rather vast area of the Halyč brick-yard working indicated that the palaeorelief was very complex and different from the modern relief. Mineral material could have been transported from the layers of older deposits during strong dust storms. Due to the large mass of transported material, during such storms the conditions were unfavourable for sufficiently long exposure of all mineral grains to sunlight. During deflation episodes mixing of material from deposit layers varying in age but situated not far apart was also possible. Low effectiveness or lack of zeroing during aeolian transport could have also resulted from the occurrence of iron oxides and carbonates as a coating of mineral grains. The presence of calcium carbonate and iron oxides was found in the studied profile. The overestimation of the TL dating results could have been also caused by a predominance of surface repeated redeposition processes (solifluction and surface washing) over aeolian accumulation in the formation of loess deposits that resulted in mixing of already deposited older material with fresh aeolian one. Such deposits form a considerable part of the loess cover in the eastern part of the brick-yard working (Bogucki et al. 2009). They could have been the source of material, which was windtransported to the west over a short distance. It is surprising that such a sedimentation model had to be rather stable as is indicated by the overestimated TL dating results determined for almost the whole Vistulian loesses in the Halych IIC profile.

The above discussion concerned the causes of the considerable overestimation of the TL dating results. The four results (Lub-4530, Lub-4519, Lub-4518, Lub-4515), rather well corresponding to the expected ages, were also over- or underestimated but to a small degree. These small deviations from the geological age can be explained in several ways. A small underestimation (e.g. for the Lub-4518 sample) can result from the incorporation of younger mineral material by bioturbation processes, periglacial cryogenic phenomena and filling of soil fissures. Underestimation of TL ages could have also resulted from the occurrence of anomalous fading. Berger et al. (2008) remind that in the opinion of many authors the TL age of feldspar-bearing samples is always underestimated 
due to this phenomenon. The TL age underestimation may be also caused by disturbed radioactivity level due to disturbed movement of groundwater. The soil-moisture fluctuations had to be considerable due to the situation of the site in the watershed area and shallow occurrence of impermeable layer (Bluszcz, 2000). We should also mention another cause of small deviations of the TL dating results from the expected ages. In case of small, comparable with a random error of TL dating method, age differences between the successive layers dated in a profile, an inversion of the results can be obtained, i.e. the TL age of the lower lying layer is younger than that of the higher lying layer, e.g. the samples Lub-4519 and Lub-4518. From statistical point of view such cases are unavoidable (Bluszcz, 2000).

\section{CONCLUSIONS}

In this paper we report the results of TL dating of the Halych IIC profile. They give new information about the influence of local conditions on the results of TL analysis. Many obtained results are distinctly overestimated, that is untypical of loess profiles. It should be stressed that the obtained results are not worthless - they give information about the conditions of transport and deposition of mineral material in the site environs during the last loess accumulation in the Early Vistulian, Plenivistulian and Late Glacial.

The overestimated TL dating results obtained for two sites in the Halych Prydnistrov'ja (Halych IIC and Kolodiiv) indicate how this region is unique among the loess areas of SE Poland and NW Ukraine in respect of the conditions of mineral material transport and deposition. Further investigations are necessary (e.g. Lian and Huntley, 1999) to identify the reasons for regular overestimating of the TL results obtained for loess deposits of the Halych Prydnistrov'ja region.

\section{ACKNOWLEDGEMENT}

This work has been done as part of the project NN306 426234 financed by the Polish Ministry of Science and Higher Education. Thanks to the late Glenn W. Berger for valuable comments on an earlier version of this manuscript. We would like to express our gratitude to Dr. Maria Wilgat who prepared the English version of this paper and to Mgr. Ewa Sadowska for the graphic preparation of the figures.

\section{REFERENCES}

Adamiec G and Aitken MJ, 1998. Dose-rate conversion factors: update. Ancient TL 16, 2: 37-50.

Aitken MJ, 1998. Introduction to Optical Dating. Oxford University Press, Oxford: $262 \mathrm{pp}$.

Balescu S, Packman SC and Wintle AG, 1991. Chronological separation of interglacial raised beaches from Northwestern Europe using thermoluminescence. Quaternary Research 35(1): 91-102, DOI 10.1016/0033-5894(91)90097-O.

Benea V, Vandenberghe D, Timar A, Van den Haute P, Cosma C, Gligor M and Florescu C, 2007. Luminescence dating of Neolithic ceramics from Lumea Noua, Romania. Geochronometria 28: 9-16, DOI 10.2478/v10003-007-0027-9.

Ber A, 2002. O zasięgu zlodowacenia Wisły w Polsce Północnowschodniej na podstawie ba-dań geomorfologicznych i termoluminescencyjnych (About the extent of the Vistulian glaciation in north-eastern Poland, based on geomorphological and thermoluminescence investigations). Przeglad Geograficzny 74, 2, 243-247 (in Polish).

Berger GW, 1987. Thermoluminescence dating of the Pleistocene Old Crow tephra and adjacent loess, near Fairbanks, Alaska. Canadian Journal of Earth Science 24(10): 1975-1984, DOI 10.1139/e87188.

Berger GW, 1988. Dating Quaternary events by luminescence. In: Easterbrook DJ ed., Dating Quaternary sediments. Geological Society of America, Special Paper 227: 13-50.

Berger GW, 1995. Progress in luminescence dating methods for Quaternary sediments. In: Rutter NW and Catto N, eds. Dating methods for Quaternary deposits. Geological Association of Canada, GEOtext 2: 81-103.

Berger GW and Anderson PM, 2000. Extending the geochronometry of arctic lake cores beyond the radiocarbon limit by using thermoluminescence. Journal of Geophysical Research 105(D12): $15439-$ 15455, DOI 10.1029/2000JD900018.

Berger GW, Pérez-González A, Carbonell E, Arsuaga JL, Bermúdez de Castro J-M and $\mathrm{Ku}$ T-L, 2008. Luminescence chronology of cave sediments at the Atapuerca paleoanthropological site, Spain. J. Human Evolution 55, 300-311.

Berger GW, Pillans BJ and Palmer AS, 1992. Dating loess up to $800 \mathrm{ka}$ by thermoluminescence. Geology 20(5): 403-406, DOI 10.1130/0091-7613(1992)020<0403:DLUTKB >2.3.CO;2.

Bluszcz A, 2000. Datowanie luminescencyjne osadów czwartorzędowych - teoria, ograniczenia, problemy interpretacyjne (Luminescence dating of Quaternary sediments - theory, limitations, interpretation problems). Zeszyty Naukowe Politechniki Ślaskiej, seria Mat. Fiz., Z. 86, Geochronometria, 17: 104 pp. (in Polish)

Bogucki (Boguckyj) AB and Łanczont M, 2002. Stratygrafia lessów Naddniestrza Halickiego (Loess stratigraphy in the Halyč Prydnistrov'ja region). In: Madeyska T, ed., Lessy i paleolit Naddniestrza halickiego (Ukraina) (Loess and Palaeolithic of the Dniester River Basin, Halyč region (Ukraine)). Studia Geologica Polonica 119: 315-327 (in Polish).

Bogucki A, Łanczont M, Sytnyk O, Madeyska T, Kusiak J, Fedorowicz S, Dmytruk R, Jacyshyn A, Dumas I and Hołub B, 2009. Halicz II - problemy stratygrafii paleolitu Prydnister'a (Paleolithic site Halych II. Problems of stratigraphy and chronology). Materialy ta doslidzennja $z$ archeologii Prykarpattja $i$ Wolyni (Materials and studies on Archeology of Sub-Carpathian and Volhynian Area) 13, Instytut Ukrainozawstwa im. I. Kryp'jakewycza NAN Ukrainy, L'wiw: 17-46 (in Ukrainian).

Brumby S, 1992. Regression analysis of ESR/TL dose-response data. Nuclear Tracks and Radiation Measurements 20(4): 595-599, DOI 10.1016/1359-0189(92)90010-S.

Fedorowicz S, 2006. Metodyczne aspekty luminescencyjnego oznaczania wieku osadów neoplejstoceńskich Europy Środkowej (Methodological aspects of luminescencje dating of Central Europe's Neopleistocene deposits). Wydawnictwo Uniwersytetu Gdańskiego: $156 \mathrm{pp}$ (in Polish).

Gozhik P, Shelkopyas V and Khristoforova T, 1995. Development Stages of Loessial and Glacial Formations in Ukraine (Stratigraphy of Loesses in Ukraine). Annales UMCS, sec. B, 50, Lublin: 65-74.

Gozhik P, Matviishina Zh, Gerasimenko, Rekovets L and Shelkoplyas V, 2001. Quarternary stratigraphy. INQUA-SEQS, Subcommission on European Quaternary Stratigraphy, The Ukraine Quaternary Explored: the Middle and Upper Pleistocene of the Middle 
Dnieper Area and its importance for the East-West correlation, Kyiv, Excursion guide: 3-62.

Grün R, 1994. Fit-Sim. Computer program, QDRC, Canberra.

Huntley DJ and Lamothe M, 2001. Ubiquity of anomalous fading in Kfeldspars and the measurement and correction for it in optical dating. Canadian Journal of Earth Sciences 38(7): 1093-1106, DOI 10.1139/e01-013.

Kusiak J, 2006. Lessy górnoplejstoceńskie Polski południowowschodniej i Ukrainy północno-zachodniej w świetle datowań termoluminescencyjnych (The Upper Pleistocene loesses of the south-eastern Poland and north-western Ukraine in the light of thermoluminescence dating). Rozprawa doktorska (PhD thesis), Archiwum UMCS: 131 pp (in Polish).

Kusiak J, 2007. True and anomalous TL dates from Late Pleistocene loess-palaeosol deposits at the Kolodiiv site (East Carpathian Foreland, Ukraine). Geological Quarterly 51 (2): 167-172.

Kusiak J, Łanczont M and Bogucki A, 2012. New exposure of loess deposits in Boyanychi (Ukraine) - results of thermoluminescence analyses. Geochronometria 39(1): 84-100, DOI 10.2478/s13386011-0054-1.

Lian OB and Huntley DJ, 1999. Optical dating studies of postglacial aeolian deposits from the south-central interior of British Columbia, Canada. Quaternary Science Reviews 18(13): 1453-1466, DOI 10.1016/S0277-3791(98)00085-7.

Lian OB and Roberts RG, 2006. Dating the Quaternary: progress in luminescence dating of sediments. Quaternary Science Reviews 25(19-20): 2449-2468, DOI 10.1016/j.quascirev.2005.11.013.

Lu Y, Prescott JR, Robertson GM and Hutton JT, 1987. Thermoluminescence dating of the Malan Loess at Zhaitang, China. Geology 15(7): $\quad 603-605, \quad$ DOI 7613(1987)15<603:TDOTML>2.0.CO;2.

Łanczont $\mathrm{M}$ and Bogucki (Boguckyj) A, 2002. Badane profile lessowe i stanowiska paleolittyczne Naddniestrza Halickiego (The examined loess sites in the Halyč Prydnistrov'ja region). In: Madeyska T, ed,
Lessy $i$ paleolit Naddniestrza halickiego (Ukraina) (Loess and Palaeolithic of the Dniester River Basin, Halyč region (Ukraine)). Studia Geologica Polonica 119: 33-181 (in Polish).

Łanczont M and Bogucki (Boguckyj) A, 2007. High-resolution terrestrial archive of climatic oscillations during Oxygen Isotope Stages 5-2 in the loess-palaeosol sequence at Kolodiiv (East Carpathian Foreland, Ukraine). Geological Quarterly 51 (2): 105-126.

Mojski JE, 1999. Drobne jednostki stratygraficzne piętra wisły w obszarze perybałtyckim (Small stratigraphic units of Vistulian in the Peribaltic area). Przeglad Geologiczny 47(3): 247-254 (in Polish).

Olley JM, Murray A and Roberts GR, 1996. The effects of disequilibria in the uranium and thorium decay chains on burial dose rates in fluvial sediments. Quaternary Science Reviews 15(7): 751-760, DOI 10.1016/0277-3791(96)00026-1.

Oczkowski HL, 2002. Komentarz fizyka do uwag Andrzeja Bera na temat artykułu $\mathrm{H}$. Banaszuka (The physicist comment on the Andrzej Ber remarks about the article published by $\mathrm{H}$. Banaszuk). Przeglad Geograficzny 74(2): 249-253 (in Polish).

Poręba G and Fedorowicz S, 2005. Gamma spectrometry for OSL and TL dating of loess deposits at Dybawka and Tarnawce (SE Poland). Geochronometria 24: 27-32.

Prescott JR and Hutton JT, 1994. Cosmic ray contributions to dose rates for luminescence and ESR dating: large depths and long-term time variations. Radiation Measurements 23(2-3): 497-500, DOI 10.1016/1350-4487(94)90086-8.

Singhvi AK, Sharma YP and Agrawal DP, 1982. Thermoluminescence dating of sand dunes in Rajastan, India. Nature 295(5847): 313315 , DOI 10.1038/295313a0.

Wintle AG, 1981. Thermoluminescence dating of the late Devensian loesses in southern England. Nature 289(5797): 479-480, DOI $10.1038 / 289479 \mathrm{a} 0$

Wintle AG and Huntley DJ, 1982. Thermoluminescence dating of sediments. Quaternary Science Reviews 1(1): 31-53, DOI 10.1016/0277-3791(82)90018-X. 